\title{
Terrestrial deposits on intertidal sandflats: sediment characteristics as indicators of habitat suitability for recolonising macrofauna
}

\author{
Vonda Cummings ${ }^{1, *}$, Simon Thrush ${ }^{1}$, Judi Hewitt ${ }^{1}$, Alf Norkko ${ }^{1,2}$, Stuart Pickmere ${ }^{1}$ \\ ${ }^{1}$ National Institute of Water and Atmospheric Research, PO Box 11-115, Hamilton, New Zealand \\ ${ }^{2}$ Present address: Department of Marine Ecology, Göteborg University, Kristineberg Marine Research Station, \\ 45034 Fiskebäckskil, Sweden
}

\begin{abstract}
Elevated rates of sedimentation as a result of human activities is a recognised problem in many marine environments. Thus, it is important to develop a mechanistic understanding of the impact and subsequent recovery of terrestrial sediment deposits in these areas. This paper describes an experiment to investigate possible reasons for the slow recovery of intertidal soft-sediment macrofaunal communities following smothering by storm-associated terrestrial sediment deposits. We measured, and monitored changes in, a large number of physical and biogeochemical properties of terrestrially derived sediments, in order to identify those characteristics that were most important to potential colonists. Properties of the terrestrial sediments were remarkably different to those of the surrounding sandflat and showed little signs of change over the duration $(4.5 \mathrm{mo})$ of the experiment. Despite this, we were able to identify that temporal changes in macrofaunal community composition were strongly correlated with the levels of chl $a$, total carbohydrate, phosphorus $(\mathrm{P})$, nitrogen $(\mathrm{N})$ and coarse sand in the sediments. We recommend that future studies of macrofaunal recolonisation following deposition of terrestrial sediment should include measurement of these sediment properties. In addition, analyses which isolate the biologically available portions of carbohydrate, $\mathrm{P}$ and $\mathrm{N}$ may provide even more insight as to the importance of these properties as settlement cues and indicators of recovery. We also assessed the influence on macrofaunal communities of the conditioning the sediment receives prior to being deposited on the sandflat (i.e. mixing with seawater or freshwater), and found no effect of this on the impact on existing macrofaunal communities or on the subsequent recovery of sediments or macrofauna.
\end{abstract}

KEY WORDS: Sedimentation · Intertidal soft-sediments · Terrestrial sediment deposits · Macrofauna • Recolonisation $\cdot$ Sediment characteristics

\section{INTRODUCTION}

Elevated rates of sedimentation in near-shore marine environments are of global concern, and several studies have indicated the broad scale degradation of valuable habitats due to massive inputs of sediment (McKnight 1969, Peterson 1985, Lundin \& Linden 1993, GESAMP 1994, Gray 1997, Ellis et al. 2000). Deposits from individual sedimentation events have been detected several $\mathrm{cm}$ deep and, especially in areas sheltered from wind-wave disturbance, they can be persistent and result in long-term degradation and alteration of the habitat due to smothering of infauna, increased turbidity and changes in sediment grain size. However, there is presently no clear mechanistic understanding of why these deposits remain so 'unattractive' to colonists long after their introduction to the marine environment. Here, we describe the properties of terrestrially derived sediments deposited in an intertidal, soft-sediment habitat, in order to identify those characteristics that are most important to potential colonists.

The role of human activities in elevating the input of terrestrially derived sediment to marine areas has been recognised for decades and is well documented (e.g. Meade 1969, Milliman \& Meade 1983, Shaffer \& Parks 1994, Cundy et al. 1998). For example, there are nu- 
merous records of elevated sediment loads to waterways resulting from catchment development, deforestation and road building activities (e.g. Megahan \& Kidd 1972, Doeg \& Koehn 1990, Fahey \& Coker 1992, Davies \& Nelson 1993, Grayson et al. 1993). Fine sediments which are removed from the land in this way may find their way to coastal areas within hours/ minutes (Fahey \& Coker 1992), particularly in association with flood events (Nichols 1977, Wheatcroft et al. 1997, Wheatcroft 2000). On mixing with seawater, fine terrestrial sediments flocculate and can settle onto the seafloor; their accumulation on the seafloor can adversely affect the resident benthic communities (Johnston et al. 1981, Fahey \& Coker 1992). In storm-associated sedimentation, terrestrial sediment may be washed into a catchment stream and transported downstream to the estuary, after which it may be deposited directly onto the sandflat, or remain in suspension for a time prior to deposition. Thus, the sediment can be mixed to a varying degree with seawater and freshwater, and the fluidity of the deposits will also vary.

In marine soft-sediment habitats in New Zealand, catastrophic inputs of terrestrial sediment associated with storm events often occurs on such a scale that large areas can be smothered and essentially, defaunated (McKnight 1969, Johnston et al. 1981, Foster \& Carter 1997, Burd et al. 2000). For example, following a storm event in the Whangapoua Estuary in 1995, a $10 \mathrm{~cm}$ deep deposit of terrestrial sediment covered an entire sandflat. This resulted in smothering of the resident fauna, including extensive shellfish and seagrass beds, and the subsequent recovery of the macrofaunal communities took several years (authors' unpubl. obs.). Slow recovery has also been noted following other naturally occurring large-scale deposition events (Foster \& Carter 1997, Burd et al. 2000). In an experiment designed to mimic the deposition of terrestrial sediments on an intertidal sandflat, Norkko et al. (2002) monitored the response and subsequent recovery of the macrofaunal community for 13 mo. The terrestrial sediments induced hypoxia and anoxia on the sandflat, killed all fauna resident under the deposits, affected biogeochemical fluxes, and essentially altered the habitat. While recovery was still incomplete at the end of the experiment, Norkko et al. (2002) were able to illustrate that remobilisation of the terrestrial sediments via bioturbation by crabs, and transport of ambient sediments on to the surface of the deposits with bedload, were important facilitators of macrobenthic recovery.

Terrestrial sediments that are deposited during catastrophic events differ from marine sediments in terms of their physical (e.g. grain size, penetrability) and biogeochemical (e.g. microbial composition, nitrogen [N] and phosphorus $[\mathrm{P}]$ content, nutritive value to benthos) composition. They frequently contain a large propor- tion of silt and clay-sized particles, are enriched with organic matter, and levels of high-quality food (estimated by chl a content) are significantly depleted (Norkko et al. 2002). Once deposited on a sandflat, their properties will be further modified. For example, when deposition results in smothering of infauna, oxygen is depleted and levels of hydrogen sulphide are elevated (e.g. similar effect to the smothering associated with algal mats; Hansen \& Kristensen 1997, Tallqvist 2001, Fetzer et al. 2002). As organisms will respond to such factors in different ways, they will obviously influence the potential for recolonisation of the deposits by macrofauna and ultimately, their recovery.

The importance of other biogeochemical properties, such as levels of ammonia, biofilms and microphytobenthos, as cues of habitat suitability for potential colonists is being increasingly recognised (e.g. Flemming \& Delafontaine 2000). Studies by Woodin et al. (1998) and Marinelli \& Woodin (2002) have shown that gradients of oxygen and ammonia in near-surface (top few $\mathrm{mm}$ ) sediments are altered by short-term (h), smallscale disturbances, such as those caused by natural sediment erosion and deposition, and that individual organisms can detect these changes. Properties of biofilms that accumulate on estuarine sediment surfaces can also provide information on habitat suitability. Biofilms are a product of complex assemblages of algal diatoms and bacterial communities and contain, among other things, carbohydrate and protein. Changes in quantities of these substances in surface sediments may reflect the breakdown of these exudates by microbes and the subsequent release of nutrients into the pore-water for use by microphytobenthos. There is a strong, positive correlation between the amount of microphytobenthos and colloidal carbohydrate present and the stability/erodability of the sediment (e.g. Sutherland et al. 1998).

Valuable additional information can be gained from estimating the portions of these biofilms that are biologically available to the fauna as a high-quality food source, rather than just presenting bulk values (Mayer et al. 1986, 1995, Sutherland et al. 1998). However, these methods are more time-consuming, expensive, and require a number of replicates for each sample collected, essentially limiting the number and types of sediment properties that can be realistically measured in a study with limited resources. Thus, measuring numerous bulk properties is a good approach towards initially isolating potentially important properties, which can subsequently be studied in more detail.

This paper describes the results of an experiment designed to investigate possible reasons for the slow recovery of macrofaunal communities following smothering by terrestrial sediment deposits. The experiment was designed to measure and monitor (1) temporal changes in biological, chemical and physical properties 
of the sediment, as well as (2) macrofaunal recolonisation, for several months following defaunation, and (3) to identify possible cause-effect relationships between these. Lastly, as the sediment may enter the estuary in a number of ways in association with a storm event (e.g. mixing with seawater or freshwater), we also investigated whether the macrofaunal recovery differed with the 'conditioning' the terrestrial sediment receives prior to its deposition on the sandflat.

\section{MATERIALS AND METHODS}

Study area. The study was conducted on an intertidal sandflat in the Whangapoua Estuary, on the eastern side of Coromandel Peninsula, North Island, New Zealand (Fig. 1A,B). The experimental site was situated at about mid-tide level. The sandflat sediments are mainly sands (fine sand $30.29 \%$ volume, medium sand $60.76 \%$ and coarse sand $8.58 \%$ ) with very little silt $(0.36 \%)$ and no clay.

The estuary is surrounded by steep, mainly forested catchment on 3 sides, and is open to the sea on the northwestern side. The catchment soils are comprised mainly of moderately to strongly leached central brown granular clays (Orbell 1973).

Experimental treatments and set-up. We identified 3 scenarios for storm-associated sedimentation.

50:50 freshwater:terrestrial sediment: Terrestrial sediment is washed into a catchment stream, transported downstream to the estuary and deposited immediately on the sandflat. Therefore, the sediment is mixed mostly with freshwater prior to deposition. This treatment will be referred to as ' $\mathrm{F} 50$ '.

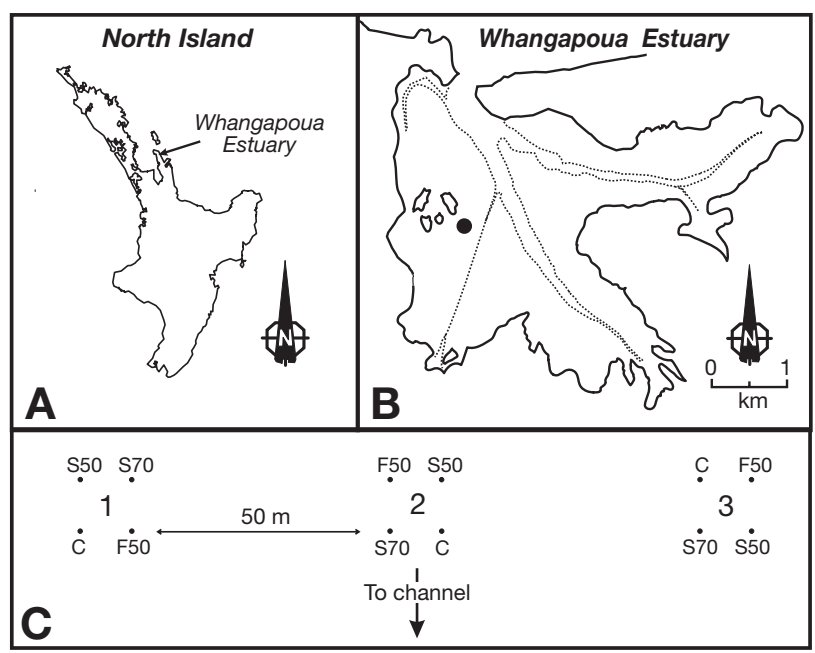

Fig. 1. (A) Whangapoua Estuary, North Island, New Zealand. (B) The study site $(\bullet)$ in the Whangapoua Estuary. (C) The arrangement of the experimental treatments in each block (1 to 3$)$
50:50 seawater:terrestrial sediment: Terrestrial sediment is washed into a catchment stream, transported downstream to the estuary, and remains in suspension for a time prior to being deposited onto the sandflat. Therefore, the sediment is mixed mostly with seawater prior to deposition. This treatment will be referred to as 'S50'.

As the terrestrial sediment entering the estuary does so most likely when the tide is covering the sandflat, both the F50 and S50 treatments were added during a high tide period.

70:30 seawater:terrestrial sediment: This treatment was included to determine the effect of a more fluid seawater:sediment mix. It was added when the sandflat was exposed during a low tide period, and will be referred to as 'S70'.

All 3 terrestrial sediment treatments resulted in $10 \mathrm{~cm}$ deep deposits in the $1 \mathrm{~m}$ in diameter experimental plots. A control treatment with no terrestrial sediment added was also included. Treatments were replicated 3 times, and replicates of each treatment were arranged in a randomised block design (Fig. 1C). Blocks were arranged parallel with the adjacent channel, with $50 \mathrm{~m}$ between each block. Individual replicates within a block were separated by $10 \mathrm{~m}$. The sediment-water mixtures referred to are weight percentages.

Experimental set-up. The terrestrial sediment used in the experiment was collected from the Whangapoua catchment, in an area of forest being cleared for road building. At source this sub-surface sediment was comprised of $2.76 \%$ clay, $38.50 \%$ silt, $56.02 \%$ fine sand and $2.72 \%$ medium sand. After excavation, the sediment was coarsely sieved ( $4 \mathrm{~cm}$ mesh), loaded into concrete mixer trucks and freshwater or saltwater was added to create a slurry of known concentration. Freshwater for mixing was pumped into the mixer from a nearby stream, while saltwater was pumped from the estuary. The slurries were mixed overnight. The next day, the appropriate slurry for each treatment was loaded into a monsoon bucket, delivered to the estuary via helicopter, and deposited into the circular experimental plots on the sandflat.

The F50 and S50 plots were set up on February 3, 1999, while the S70 and control plots were set up on February 4, 1999. The F50 and S50 treatment plots were prepared by inserting a plastic ring around the plot perimeter when the sandflat was uncovered by the tide. The ring protruded $1.8 \mathrm{~m}$ above the sediment surface. As the tide covered the sandflat the rings gradually filled with seawater, and at high tide the top of the rings were still above the water level, preventing any loss of the mix. Once high tide was reached, the mix was deposited into the rings. The rings were kept in place until the water had drained from the sandflat, 
and were then carefully removed. The S70 and control treatment plots were prepared by inserting a metal ring into the sediment so that $10 \mathrm{~cm}$ protruded. The clay was deposited into the S70 treatment rings when the sandflat was uncovered by the tide. The rings surrounding the S70 and control plots were removed before the next tide covered the sandflat.

Sampling. Plots were sampled for macrofauna and a variety of sediment characteristics over the $4.5 \mathrm{mo}$ (127 d) following the terrestrial sediment deposition. The exact dates of sampling and the samples collected on each occasion are given in Table 1. Sampling within the plot was done in a rotational manner, to ensure that samples were not collected from a previously disturbed position. Samples were collected at least $30 \mathrm{~cm}$ from the plot perimeter to avoid edge effects, and core holes were filled with defaunated sandflat sediment to avoid confounding effects of the plot sediments slumping into the holes.

Colonisation: Core samples were collected to monitor colonisation of the plots by settlement of new recruits and post-settlement stages $(\geq 250 \mu \mathrm{m}$; hereafter 'colonising macrofauna'), and also to assess the response of larger macrofauna $\left(\geq 500 \mu \mathrm{m}_{i}\right.$ hereafter 'macrofauna'). Colonising macrofauna samples were collected on 7 occasions. On each date, a core sample ( $5 \mathrm{~cm}$ in diameter, $2 \mathrm{~cm}$ deep) was taken, preserved in $70 \%$ isopropyl alcohol and stained with rose bengal.

Table 1. Dates of each sampling occasion, number of days since the experiment was set up and the samples collected on each day. The terrestrial sediments were deposited on February 3 (F50 and S50 treatments) and 4 (S70 treatment), 1999. Sampling days in bold are those used to denote each sampling occasion throughout the paper. 'Sediment properties' include the following: \% coarse sand, medium sand, fine sand, silt and clay, penetrability, shear stress, carbohydrate, protein, microbial biomass, chl a, phaeophytin, porewater $\mathrm{NH}_{4}-\mathrm{N}$, sediment $\mathrm{P}, \mathrm{N}, \% \mathrm{C}$ and organic content

\begin{tabular}{|c|c|c|c|}
\hline \multirow{2}{*}{$\begin{array}{l}\text { Sampling date } \\
\text { (1999) }\end{array}$} & \multicolumn{2}{|c|}{ Days since set-up } & \multirow{2}{*}{ Samples collected } \\
\hline & F50, S50 & S70, control & \\
\hline 2 Feb & -1 & -2 & Macrofauna \\
\hline $9 \mathrm{Feb}$ & 6 & 5 & $\begin{array}{l}\text { Sediment properties, } \\
\text { colonising macrofauna, } \\
\text { macrofauna }\end{array}$ \\
\hline 16 Feb & 13 & 12 & $\begin{array}{l}\text { Sediment properties, } \\
\text { colonising macrofauna }\end{array}$ \\
\hline 26 Feb & 23 & 22 & $\begin{array}{l}\text { Sediment properties, } \\
\text { colonising macrofauna }\end{array}$ \\
\hline $11 \mathrm{Mar}$ & 36 & 35 & $\begin{array}{l}\text { Sediment properties, } \\
\text { colonising macrofauna }\end{array}$ \\
\hline $25 \mathrm{Mar}$ & 50 & 49 & $\begin{array}{l}\text { Sediment properties, } \\
\text { colonising macrofauna }\end{array}$ \\
\hline 7 May & 93 & 92 & $\begin{array}{l}\text { Sediment properties, } \\
\text { colonising macrofauna }\end{array}$ \\
\hline 11 Jun & 127 & 126 & $\begin{array}{l}\text { Sediment properties, } \\
\text { colonising macrofauna, } \\
\text { macrofauna }\end{array}$ \\
\hline
\end{tabular}

The animals retained on a $250 \mu \mathrm{m}$ sieve were later sorted, identified and counted. Larger macrofauna were sampled prior to sediment deposition (Day -2), and on 2 occasions afterwards (Days 6 and 127), using a $10 \mathrm{~cm}$ in diameter, $15 \mathrm{~cm}$ deep corer.

Sediment characteristics: Several small sediment cores (each $2 \mathrm{~cm}$ in diameter, $2 \mathrm{~cm}$ deep) were collected to assess sediment characteristics. Two cores were collected and pooled for chl $a$ analysis, 1 core for analysis of ammoniacal-nitrogen $\left(\mathrm{NH}_{4}-\mathrm{N}\right)$ in the porewater, and 3 cores were pooled and later sub-sampled for analysis of total microbial biomass, total carbohydrate, total protein, sediment $\mathrm{P}$, sediment $\mathrm{N}$ and \% particulate carbon (\% C). Surface sediment scrapes were collected and assessed for grain size and organic content. All sediment samples were immediately frozen and stored until they could be analysed.

Sediment for chl a analysis was extracted in 95\% ethanol, and the extract was processed using a spectrophotometer. An acidification step was used to separate degradation products from chl a (Sartory 1982). The sediment core for porewater $\mathrm{NH}_{4}-\mathrm{N}$ determination was centrifuged (3000 rpm, $15 \mathrm{~min}$ ), and the porewater carefully decanted and analysed using the automated phenate method (APHA 1998).

Total microbial biomass ( $\mu \mathrm{g} \mathrm{g}^{-1}$ dry wt) was measured by dichloromethane extraction of the wet sediment followed by persulphate determination of the phospholipid (Findlay et al. 1989). Total carbohydrates were estimated using the phenol-sulphuric acid method (Liu et al. 1973) which measures both the sugars and polysaccharides present. Sediment (50 to $100 \mathrm{mg}$ dry wt) was dispersed in $1 \mathrm{ml}$ of deionised water with $10 \%$ phenol and sulphuric acid. The absorbance was read in a Shimadzu UV-1601 UV-Visible spectrophotometer at $485 \mathrm{~nm}$. Following correction for a sediment-sulphuric acid blank, carbohydrate content was expressed as glucose equivalents (mg $\mathrm{g}^{-1}$ dry wt). The phenol-sulphuric acid carbohydrate analysis estimates the total sugars (pentoses and hexoses) present in the biological fraction, but does not distinguish between organisms or exudates. Total protein was assayed by a modified Lowry method (Hartree 1972). Sediment (30 to $50 \mathrm{mg}$ dry wt) was homogenised in $1 \mathrm{ml}$ deionised water and the absorbance read at $650 \mathrm{~nm}$ on a Shimadzu UV-1601 UV-Visible spectrophotometer. The results were expressed as BSA equiva- 
lents ( $\mathrm{mg} \mathrm{g}^{-1}$ dry wt). The Lowry protein method used in our study may lead to overestimates of protein content due to the presence of phenolic compounds. However, it is a relatively simple method suited to analysing large numbers of samples.

Sediment $\mathrm{P}$ and $\mathrm{N}$ ( $\mathrm{mg} \mathrm{g}^{-1}$ dry wt) were determined by Kjeldahl digestion at $300^{\circ} \mathrm{C}$ followed by ammonium-nitrogen and phosphate determination using a Technicon AAII autoanalyser. Total \% C in the sediment was measured using high temperature combustion in a Perkin Elmer $2400 \mathrm{CHN}$ analyser. Control samples were treated with $5 \mathrm{M} \mathrm{HCl}$ prior to analysis to remove any carbonate (mainly shell pieces) present.

Grain size was determined by digesting the sediments in $6 \%$ hydrogen peroxide for $48 \mathrm{~h}$ to remove organic matter, and dispersion using Calgon. A Galai particle analyser (Galai Cis - 100; Galai Productions) was then used to calculate \% volumes for the coarse, medium and fine sand, silt and clay fractions. Organic content, measured as loss on ignition (LOI), was estimated by drying the sediment at $90^{\circ} \mathrm{C}$ for $48 \mathrm{~h}$, then combusting in a muffle furnace for $5.5 \mathrm{~h}$ at $400^{\circ} \mathrm{C}$. The depth of the clay layer was also measured, along with the sediment shear strength (using a pocket shear vane) and penetrability (using a pocket penetrometer).

Statistical analyses. Univariate analyses: Univariate analyses were conducted to determine differences between experimental treatments over time, in sediment properties and count data (from the macrofauna and the colonising macrofauna cores). Count data analysed were either total number of individuals, total number of taxa, or abundant taxa (i.e. taxa occurring on average $>1$ individual per core in any plots on the majority of sampling occasions). Burrowing crabs (Helice crassa, Macrophthalmus hirtipes and Hemigrapsus crenulatus) were combined in all analyses. For 2 taxa from the colonising macrofaunal count data that were analysed for treatment effects, non-convergence was attained using generalised linear models. Thus, for these 2 variables, a rank transformation was used and an ANOVA then carried out on the ranks.

Before differences between treatments were investigated, data were checked for normality (Shapiro-Wilk test) and homogeneity of variances (Cochran's test). Sediment data based on percentages was arcsinetransformed before testing. Where sediment data did not meet ANOVA assumptions for normality and homogeneity of variances, log transformations were used. When count data did not meet these assumptions, generalised linear modelling techniques, with a Poisson error structure and a log-link function, were used. On the few occasions where such data were overdispersed, quasi-likelihood techniques were used.

Differences between experimental treatments over time were investigated using treatment and time as categorical factors and including a Time $\times$ Treatment interaction term. Significant main effects $(p<0.05)$ were investigated by using multiple contrast statements. When a significant interaction term $(\mathrm{p}<0.10)$ was found, differences between treatments were investigated for each sampling occasion separately.

Multivariate analyses: Colonising macrofaunal count data were Hellinger-transformed before principal component analysis (PCA) of the raw data was conducted, following Legendre \& Gallagher (2001). To investigate the relationship between the colonising macrofauna and sediment properties, redundancy analysis (RDA) was conducted on all treatments, and then on control treatments only. Due to analytical problems, the following data were generated to enable a full suite of sediment properties to be included in the RDA: (1) $\mathrm{NH}_{4}-\mathrm{N}$ could not be determined for the control plots on Day 50, due to insufficient porewater volumes. Therefore, this was estimated for each control plot replicate using an average of the values recorded on Days 13, 23, 36 and 93. (2) Penetrometer and shear vane measurements were not made in the control plots on Days 6, 13 or 23. Thus, an average of the values recorded from Days 36, 50, 93 and 127 was calculated for each replicate control plot, and these values were used for each missing sampling occasion. (3)\% C values were not available on Day 127. Therefore, the relationship between \% C and carbohydrate was determined, and the resultant equation used to generate corresponding values for \% C at Day $127(\mathrm{R}=0.84)$

The RDAs identified a number of highly correlated sediment properties, especially \% clay content. Forward selection was conducted to determine the important sediment variables (canonical correspondence analysis; ter Braak 1986, 1987), avoiding choosing highly correlated variables, such that the final model did not contain variance inflation factors $>10$. Forward selection was repeated a number of times, varying the order of variable selection to ensure that the model selected was stable.

\section{RESULTS}

\section{General observations}

The terrestrial sediment depth gradually decreased over the experiment, from an initial depth of 9 to $10 \mathrm{~cm}$ immediately after deposition, to around 4 to $6 \mathrm{~cm}$ 4.5 mo later (Day 127). Terrestrial sediment depth was quite variable within a particular plot, due to the ripples on the sandflat surface below the deposits. There were no obvious differences in depth between the different treatments. On the first few sampling dates, the 
S70 plots appeared relatively more 'smooth' and fluid than the other sediment treatments. All terrestrial sediment treatment plots remained distinct from the surrounding sediments throughout the experiment. In the initial weeks of the experiment, the weather was calm and sunny, so the sediment 'set' and dried out on the sandflat, and cracks appeared in all plots. Although the plots stayed proud of the surrounding sandflat, as time progressed their diameters shrank due to build-up of marine sediments at the plot edges. Unlike a previous experiment (Norkko et al. 2002), they did not become covered by sediment moving with the bedload, nor were they eroded by wave action. The only visible change in the terrestrial sediment plots was the appearance of numerous tiny burrows in the clay layers on Day 23 (up to 142 burrows $0.1 \mathrm{~m}^{-2}$ ), caused by a large influx of juvenile crabs. As the experiment progressed, these burrows became larger as the crabs grew in size. Conditions throughout the experiment were calm, with very little wind-wave disturbance along with very little rainfall (authors' obs.).

\section{Macrofauna $(\geq 500 \mu \mathrm{m})$}

The sandflat sediments were dominated by spionid polychaetes (Aquilaspio aucklandica, Aonides oxycephala, Prionospio sp.) as well as the nepthyd Aglaophamus and nereids. The bivalves Nucula hartvigiana, Austrovenus stutchburyi and Macomona liliana were also common. Prior to sediment deposition (Day -2) the number of individuals found was similar in each plot, as were the number of taxa (Fig. 2). However, by Day 6, numbers in the terrestrial sediment treatments had declined markedly, and were considerably lower than those in the control plots. Samples taken from terrestrial sediment plots in a companion study showed that all macrofauna under the deposits were dead after $8 \mathrm{~d}$ (Hewitt et al. in press). This companion study began on the same day as our experiment, and used terrestrial sediments identical to those used in our S70 treatment (Hewitt et al. in press). Even by the end of the experiment, $127 \mathrm{~d}$ later, the abundance and diversity of macrofauna in the sediment treatment plots was still significantly less than in the controls ( $p<0.0001$; Appendix 1). There were no differences in macrofaunal abundance or diversity between the 3 terrestrial sediment treatments.

\section{Colonising macrofauna $(\geq 250 \mu \mathrm{m})$}

The total number of individuals and the total number of taxa were significantly higher in the control plots than the terrestrial sediment treatment plots throughout the experiment ( $p<0.0001$; Appendix 1, Fig. 3). There were no differences in abundance of individuals or taxa between terrestrial sediment treatments.

The bivalve Nucula hartvigiana and the polychaete Lumbrinereis brevicirra ( $<1$ ind. core $\left.{ }^{-1}\right)$ were found in the control plots only, although in low numbers ( 0 to 2 and $<1$ ind. core $^{-1}$, respectively). Conversely, burrowing crabs (Macrophthalmus hirtipes and Helice crassa) were only found in the terrestrial sediment treatments. Two taxa (Aquilaspio aucklandica and nereid polychaetes) were found in both the control and terrestrial sediment treatments (Fig. 4). Neither taxon exhibited a significant Time $\times$ Treatment interaction $(p>0.15)$, and both were significantly more abundant in the control plots ( $\mathrm{p}<0.0001$; Appendix 1).

Fig. 5 illustrates the change in colonising macrofaunal community composition in the different treatments over the $127 \mathrm{~d}$ experiment in 2 dimensions. This PCA ordination explained $67 \%$ of the variability in community composition (first 4 axes), with $2 / 3$ of this variability explained by Axes 1 and 2 (Fig. 5). There is a distinct separation between the control plot and sediment treatment communities throughout the experiment (Fig. 5). While the control plot communities are very similar over the experimental period, the communities

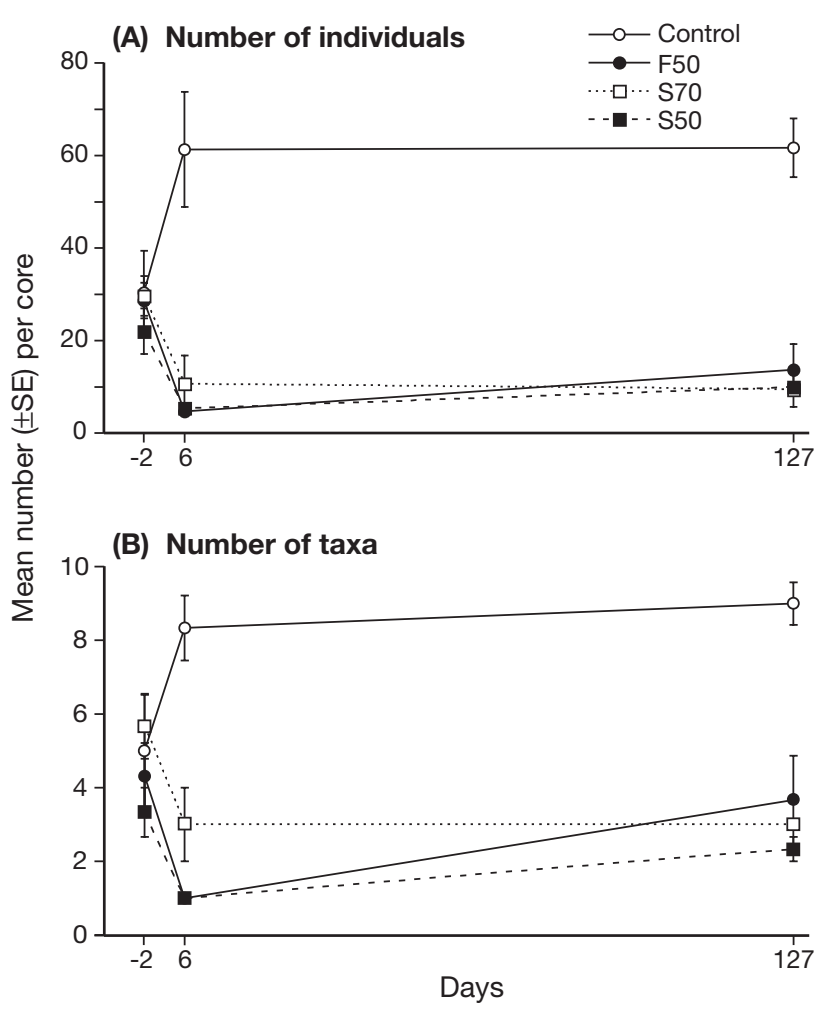

Fig. 2. Number of (A) macrofaunal $(\geq 500 \mu \mathrm{m})$ individuals and (B) taxa found in each experimental treatment at the beginning and end of the experiment. Numbers presented are means $( \pm \mathrm{SE})$ per core 


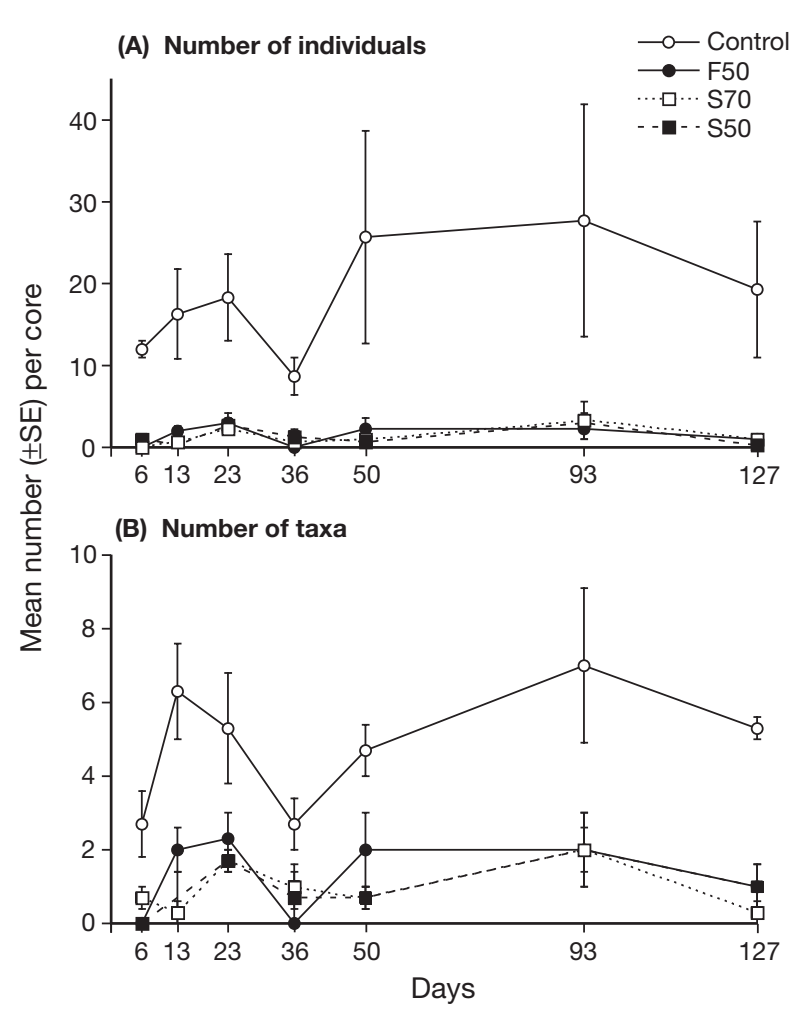

Fig. 3. Number of $(A)$ colonising macrofaunal $(\geq 250 \mu \mathrm{m})$ individuals and (B) taxa found in each experimental treatment throughout the experiment. Numbers presented are means $( \pm \mathrm{SE})$ per core

of all 3 sediment treatments exhibit large, variable changes in composition. On 2 occasions, the S70 community moved nearer to that of the control in the ordination space; however, on neither occasion were they close to the control community of that particular sampling occasion (Fig. 5), and the communities were still distinctly different (see also Figs. $3 \& 4$ ).

The relative instability of the terrestrial sediment communities is further illustrated by examining the total number of 'new' taxa colonising the plots (i.e. species that were not found in the plots on the previous sampling occasion) and the total number of taxa that were present on the previous date (Fig. 6). The control plots clearly have higher numbers of the same taxa present from one sampling occasion to the next. Interestingly, there are also a large number of new taxa found in the control plots, illustrating the transient nature of some taxa found on this sandflat.

\section{Sediment properties}

The various sediment properties measured generally show a clear difference between the control and terrestrial sediment treatments throughout the experiment,

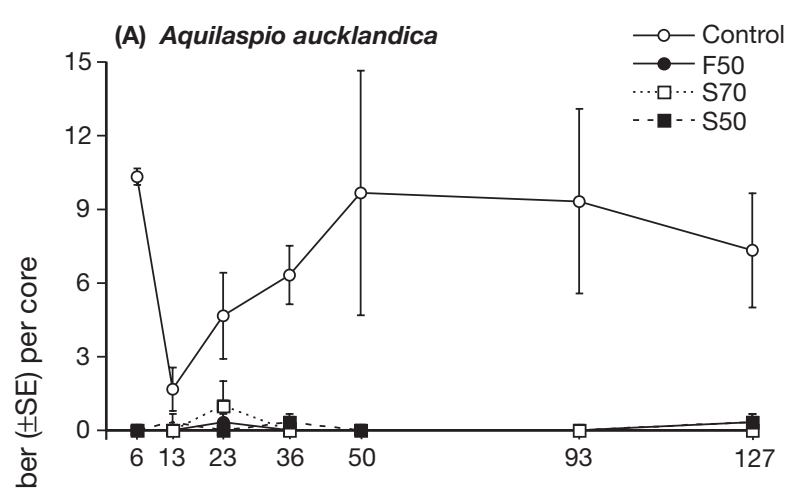

(B) Nereids

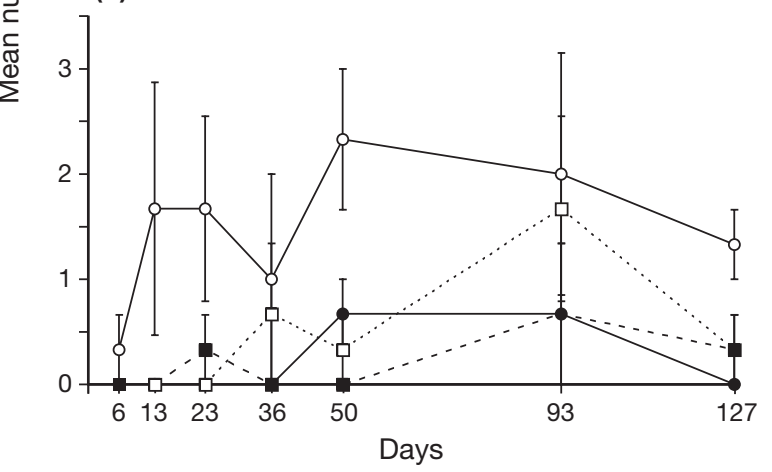

Fig. 4. Number of individuals of 2 taxa, (A) Aquilaspio aucklandica and (B) nereids, found in each experimental treatment throughout the experiment. Numbers presented are means $( \pm \mathrm{SE})$ per core

but there was no consistent distinction between the properties of the 3 terrestrial sediment treatments (with the exception of protein). The terrestrial sediments have consistently lower levels of porewater $\mathrm{NH}_{4}-\mathrm{N}$, coarse and medium sand, chl $a$ and chl a:phaeophytin ratio, and higher levels of carbohydrate, protein, $\mathrm{N}, \mathrm{P}$, $\% \mathrm{C}, \%$ organic content, fine sand, silt, clay and shear strength relative to the control treatment sediments. Microbial biomass, phaeophytin and sediment penetrability were the only properties measured which did not show a clear distinction between controls and sediment treatments throughout the experiment. These sediment properties are discussed more fully below. Details of the results of the statistical analysis of each sediment property are presented in Appendix 2. C:N and $\mathrm{C}$ :carbohydrate ratios were also investigated, but as neither proved to be a useful diagnostic tool for distinguishing between treatments, these are not presented here.

\section{Grain size}

Throughout the experiment, the control plot sediments were comprised predominantly of medium (27 to 


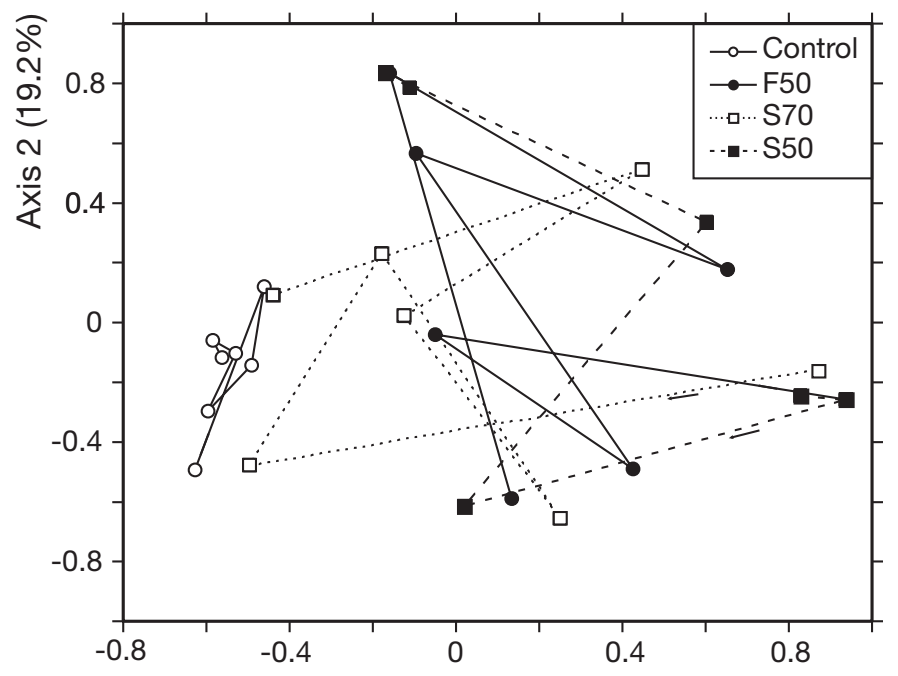

Axis $1(24.3 \%)$

Fig. 5. Hellinger-transformed colonising macrofaunal community data in each experimental treatment on each sampling occasion, produced by principal component analysis.

Points are connected in time sequence. The \% variance explained by each axis is also given
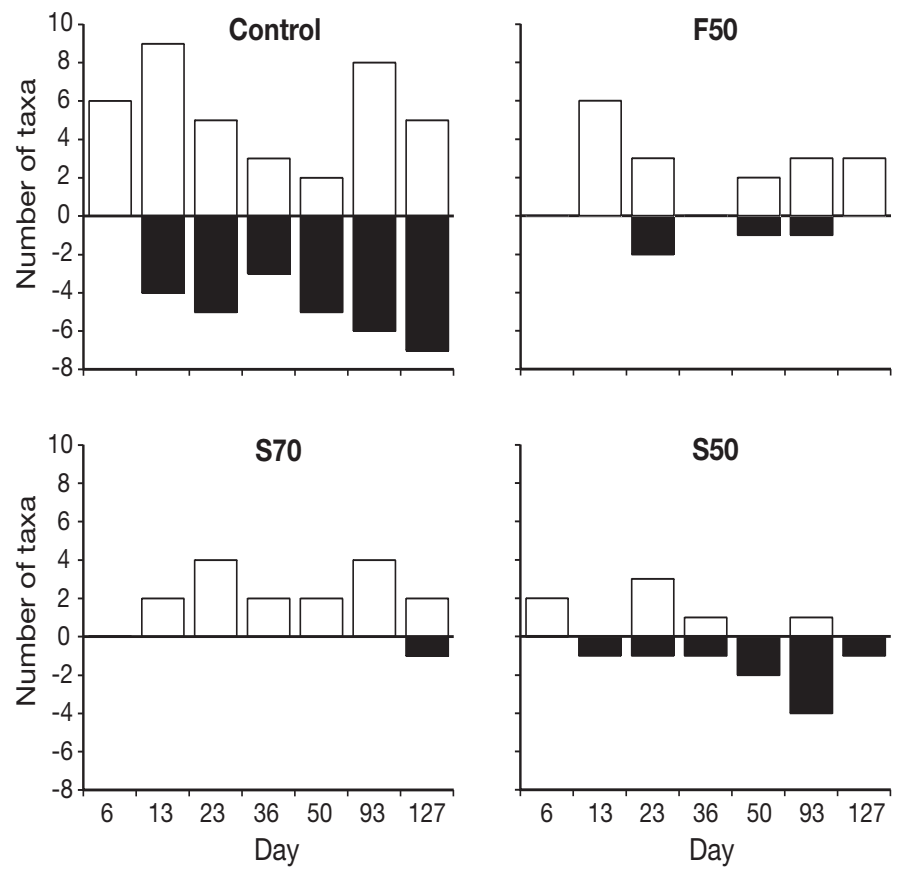

$\square$ New taxa

Taxa also present on previous sampling date

Fig. 6. Total number of 'new' taxa colonising the plots (i.e. species that were not found in the plots on the previous sampling occasion) and the total number of taxa that were also present on the previous date, in each experimental treatment on each sampling occasion
$66 \%$ ) and fine (22 to $62 \%$ ) sand, with 6 to $11 \%$ coarse sand and a very small fraction of silt ( 0.24 to $0.60 \%)$. There was no clay in the control plots on any sampling date. The amount of fine and medium sand changed gradually over the course (4.5 mo) of the experiment, from around $22 \%$ fine sand and $66 \%$ medium sand on Day 6 , to $62 \%$ and $27 \%$ on Day 127 , respectively (Fig. 7).

In contrast, the terrestrial sediment treatments were generally comprised mainly of fine sand (40 to $80 \%$ ) with some silt (60 to $20 \%$ ). These treatments contained a small amount of clay $(<9 \%)$ and no coarse sand (Fig. 7). The \% silt and \% clay decreased markedly over the course of the experiment, and the \% fine sand increased accordingly (Fig. 7C-E). From Day 23 onwards, clay levels in the terrestrial sediment treatments had dropped such that some were no longer significantly different from the control sediments (Fig. 7E).

\section{Penetrability and shear strength}

The de-watering of the terrestrial sediment treatment plots over time is reflected in the measurements of sediment penetrability and shear strength (Fig. 7F,G). As the plots dried out and hardened, the sediments required more force to penetrate and dislodge sediments than was required for the control plot sediments.

Total carbohydrate, total protein and total microbial biomass

The carbohydrate and protein contents of the terrestrial sediments were significantly higher than in the control plot sediments on all sampling dates $(\mathrm{p}<$ 0.0001; Fig. 8A,B). In addition, there was significantly more protein in the $\mathrm{S} 70$ sediments than in the F50 sediments throughout the experiment. As there were substantial amounts of total carbohydrate associated with protein in our analyses, the interference by phenolic compounds (sensu Mayer et al. 1986) is likely to be low. The microbial biomass ranged from 0.1 to $2.2 \mathrm{\mu g} \mathrm{g}^{-1}$ over the experiment (Fig. 8C). While there was no distinction in microbial biomass between treatments $(p=0.8044)$, the ANOVA did detect a significant effect of time ( $p<0.0001$; Fig. 8C).

\section{Chl $a$ and phaeophytin}

Chl a was 2.3 to 13.0 times lower in the terrestrial sediment treatments than in the control plot sediments 


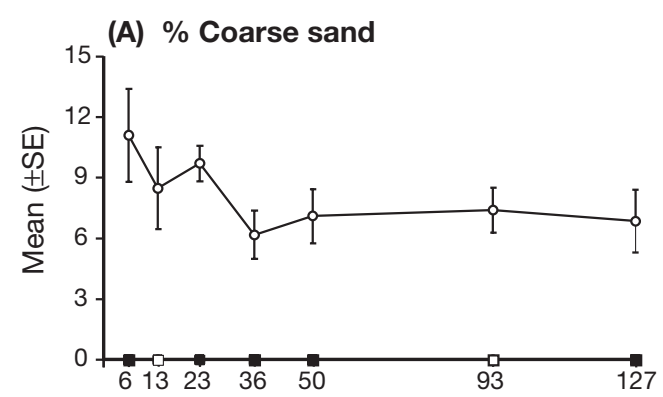

(B) \% Medium sand

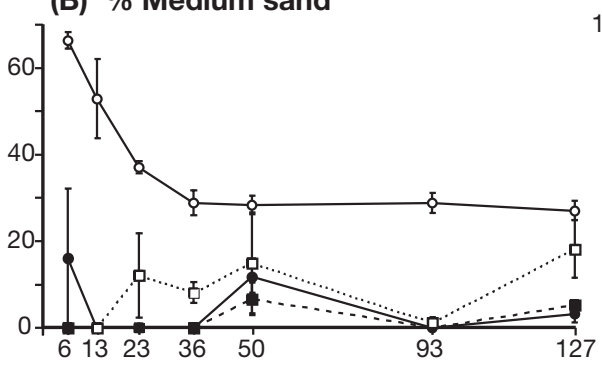

(E) \% Clay

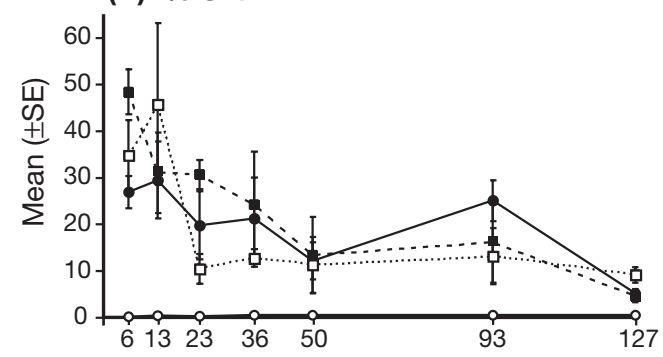

(G) Shear strength $\left(\mathrm{kg} / \mathrm{cm}^{2}\right)$
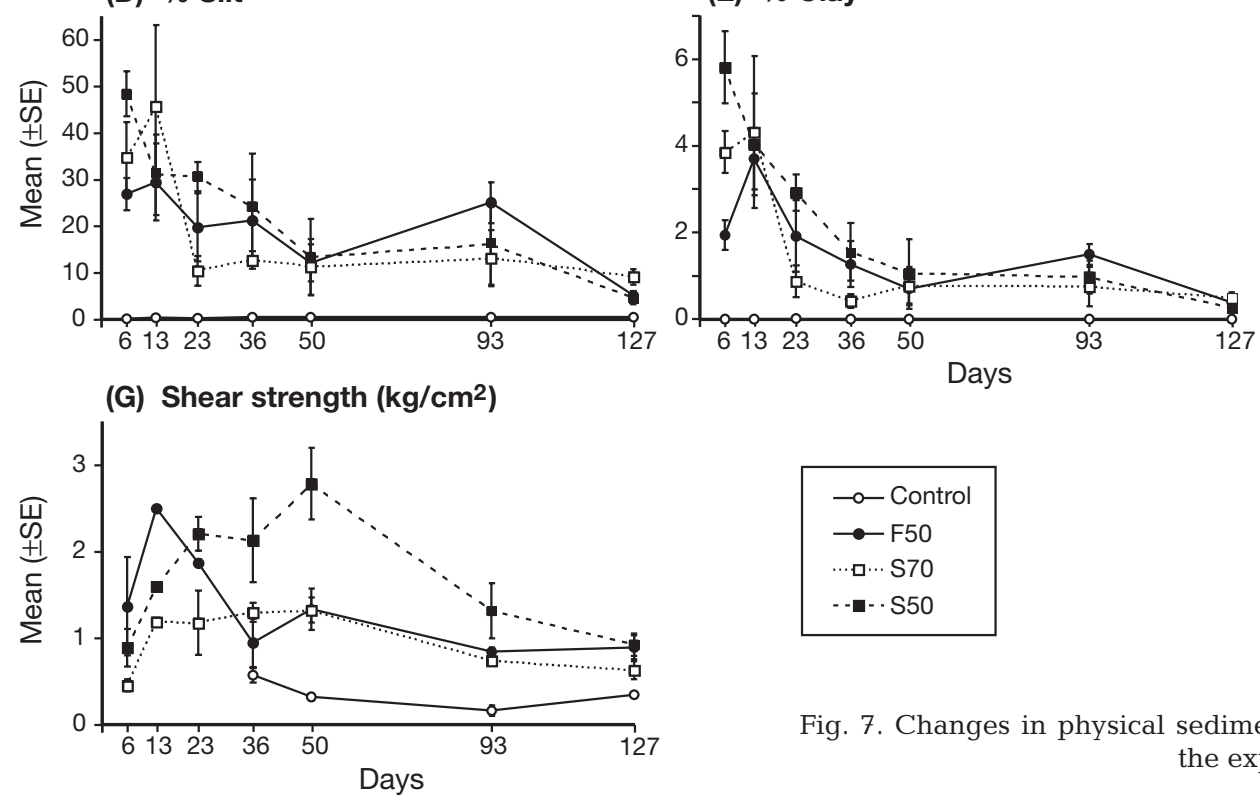

(C) \% Fine sand

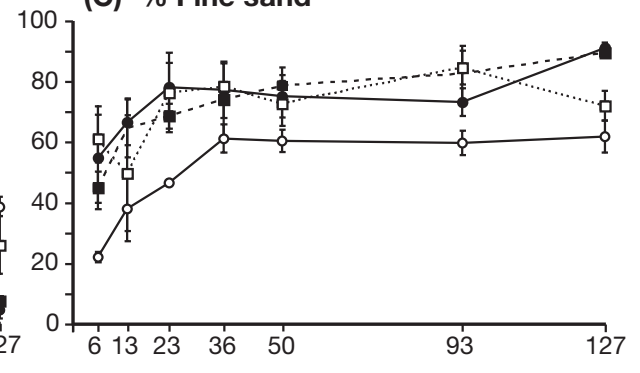

(F) Penetrability $\left(\mathrm{kg} / \mathrm{cm}^{2}\right)$

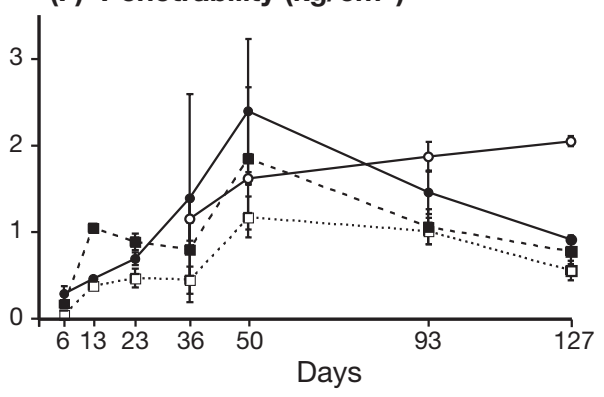

( $p<0.0001$; Fig. 8D). Although levels increased in all terrestrial sediment treatments from Day 36 onwards, they had still not reached those of the control sediments by the end of the experiment (Day 127). The level of phaeophytin, a degradation product of chl $a$, was very low $\left(<1.5 \mu \mathrm{g} \mathrm{g}^{-1}\right)$ and generally similar in all treatments throughout the experiment, with the exception of the control plot sediments on Day 127 (Fig. 8E). Consequently, the ratio of chl a to phaeophytin was always significantly lower in the terrestrial sediment plots ( $\mathrm{p}<0.0001$; Fig. 8F).

\section{Porewater $\mathrm{NH}_{4}-\mathrm{N}$, sediment $\mathrm{P}$ and $\mathrm{N}$}

The level of $\mathrm{NH}_{4}-\mathrm{N}$ in porewater was significantly lower in the terrestrial sediment treatments than the control plot sediments on all but Day 93 ( $p<0.0001$; Fig. 9A). Conversely, sediment $\mathrm{P}$ and $\mathrm{N}$ were always higher in the terrestrial sediment treatments ( $p<0.0001$; Fig. 9B,C). The temporal fluctuations in sediment $\mathrm{P}$ content mirrored those for sediment $\mathrm{N}$ in all treatments.
\% C and organic content (LOI)

There was more carbon in the terrestrial sediment treatments than the control sediments throughout the experiment ( $p<0.0001$; Fig. 9D). The organic content was also generally higher in the terrestrial sediment treatments during the experiment, with the exception of Day 23, when there were no significant differences between any of the treatments (even though the levels in the control were still very low; Fig. 9E). Although differences were found between the organic contents of the terrestrial sediment treatments, these were not consistent over time. On Day 6, the S50 sediments had a slightly higher organic content than the F50 sediments, and on Day 36, both of these treatments had higher organic contents than the S70 sediments.

\section{Colonising macrofaunal community and sediment properties}

In the RDA that included all 4 experimental treatments, 4 sediment properties (\% coarse sand, carbohy- 

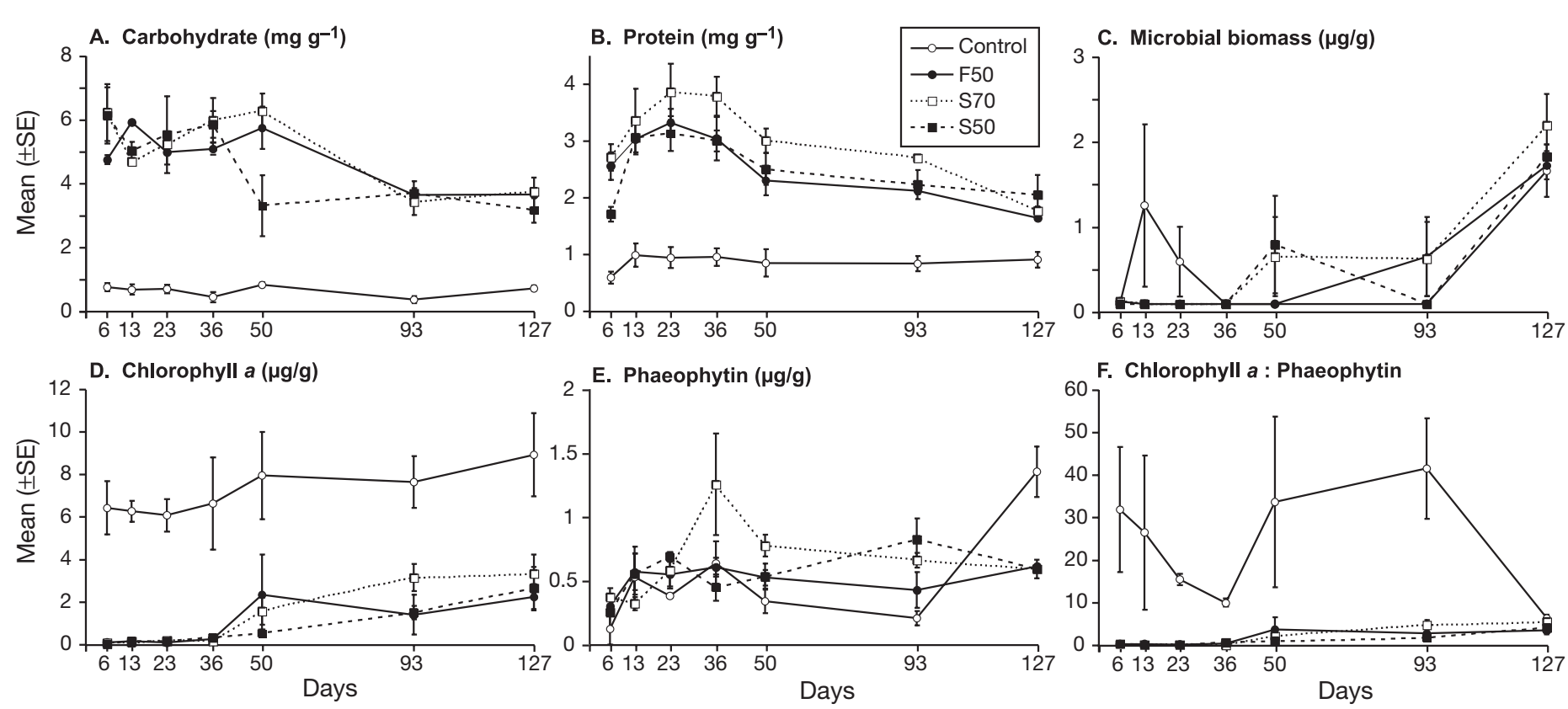

Fig. 8. Changes in biological sediment properties of each treatment over the experiment

drate, phosphorus and penetrability) explained $29.5 \%$ of the variability in the colonising macrofaunal communities between treatments. The terrestrial sediment treatments were associated with higher levels of carbohydrate and $\mathrm{P}$ and lower penetrability, while the control plot communities had a strong, positive association with coarse sand. There was no coarse sand in any of the terrestrial sediment treatments (see Fig. 7). As noted for the PCA (Fig. 5), there was distinct separation between the control and terrestrial sediment communities throughout the experiment, and much higher temporal variability in the communities of all 3 of the latter treatments. This RDA explained a reasonable amount of the variability in community composition between treatments, despite the low abundance and sporadic occurrence of colonising macrofauna and general lack of recovery in the terrestrial sediment treatments. This result was driven by the large differences in the sediment characteristics between the terrestrial sediment and control treatments throughout the experiment.
(A) Porewater $\mathrm{NH}_{4}-\mathrm{N}(\mathrm{mg} / \mathrm{l})$

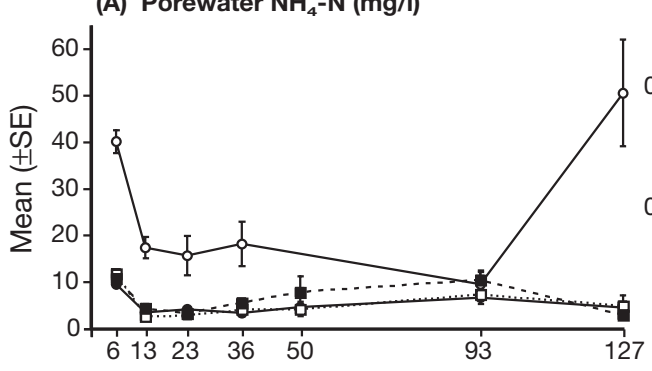

(D) \% Carbon

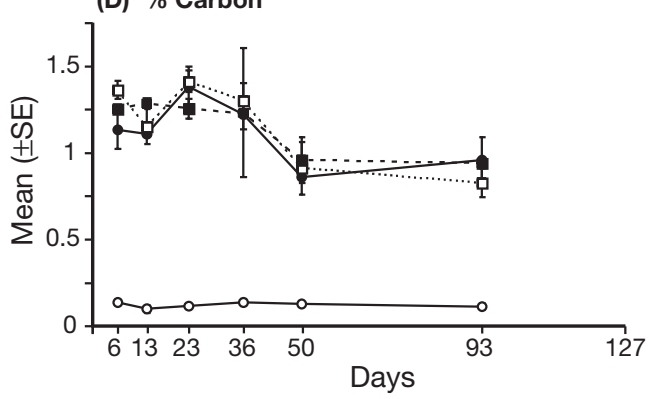

(B) Phosphorus ( $\left.\mathrm{mg} \mathrm{g}^{-1}\right)$

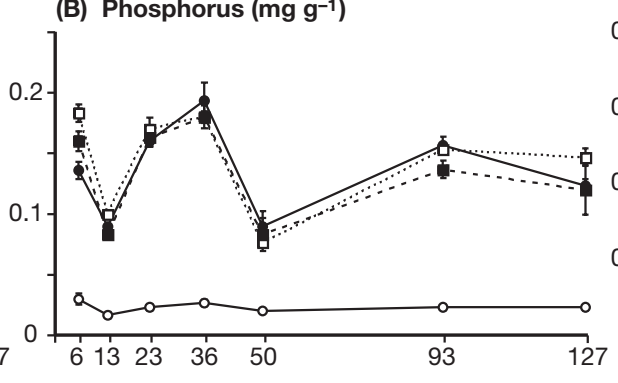

(E) \% Organic content (LOI)

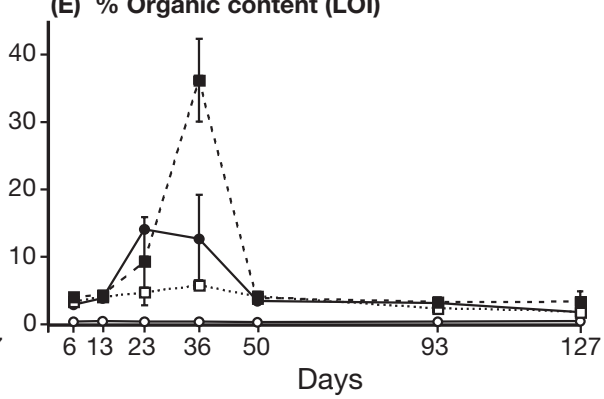

(C) Nitrogen $\left(\mathrm{mg} \mathrm{g}^{-1}\right)$

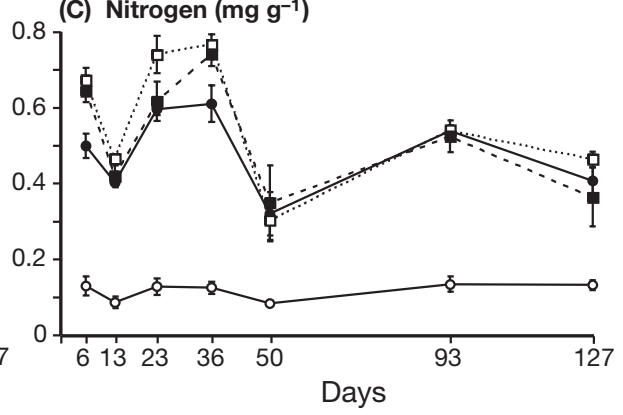

Fig. 9. Changes in chemical sediment properties of each treatment over the experiment. LOI: loss on ignition 


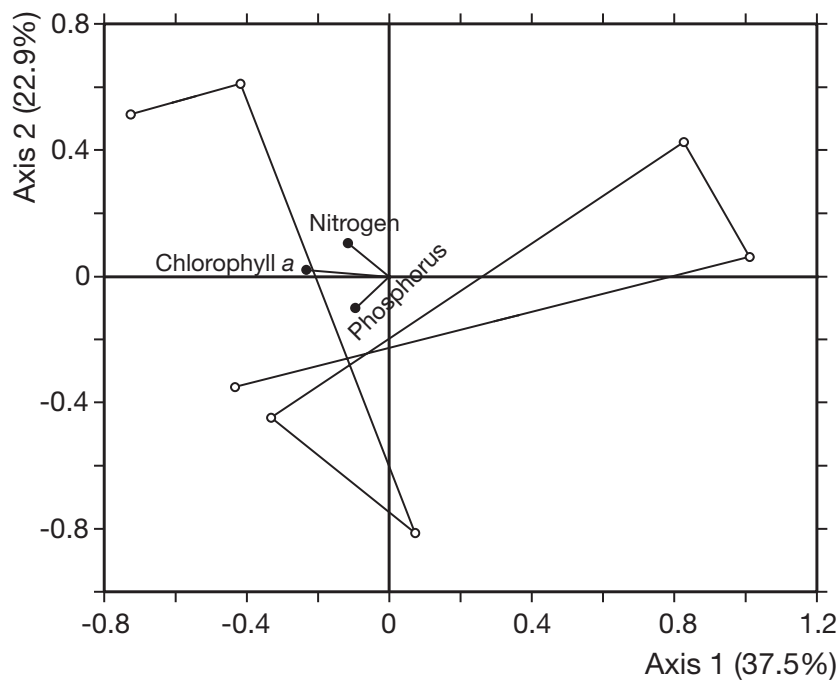

Fig. 10. Hellinger-transformed colonising macrofaunal community data in the control treatment on each sampling occasion, and the sediment properties important in explaining the variability in these communities, produced by redundancy analysis. Points are connected in time sequence. The \% variance explained by each axis is also given

Thus, to help better identify sediment properties that are important to colonising macrofauna, we conducted an additional RDA using the control treatment data only. Three properties, chl a, P and N, explained a very large amount $(76.4 \%)$ of the variability in the control communities during the experiment $(p=0.0080$; Fig. 10). The importance of these 3 properties is to some extent reflected in the summary community measures of numbers of individuals and taxa. The most important variable, chl $a$, increased over the experiment, and was associated with a slight increase in numbers of taxa (see Figs. 2B \& 8D). Higher levels of $\mathrm{P}$ and $\mathrm{N}$ tended to have a negative influence on the abundances of individuals and taxa (see Figs. 2 \& 9B, C).

\section{DISCUSSION}

The main aim of this experiment was to characterise the change in the properties of terrestrial sediment deposits on an intertidal sandflat, which occur during storm-related sedimentation events, in association with recolonisation of the deposits by macrofauna. Many different sediment characteristics were measured during the 4.5 mo experiment, all of which could be expected to evoke a response in potential colonists. By relating changes in these properties to the macrofaunal community in a multivariate way, we were able to isolate characteristics which are important as indicators of habitat suitability to macrofauna.

\section{Recovery of sediments and macrofauna}

Numbers of colonists remained very low in the terrestrial sediments throughout the experiment (i.e. mean abundance $<4$ ind., $<2$ species $\operatorname{core}^{-1}$; Fig. 3), and the same taxa were not generally found from 1 sampling occasion to the next (Fig. 6). As this experiment spanned more than 4 mo and encompassed a period of high recruitment (authors' pers. obs.), it is unlikely that recruit limitation contributed to this pattern. For example, average numbers of the spionid polychaete Aquilaspio aucklandica were reasonably high in the control plots throughout the experiment, but very few settled in the terrestrial sediments (Fig. 4). The only taxa that increased in the terrestrial sediments during the experiment were nereid polychaetes (Fig. 4). Interestingly, nereids are relatively tolerant of reduced levels of oxygen (Norkko 1998) and are known to modify nutrient fluxes in muddy sediments through their burrowing activities (Hansen \& Kristensen 1997, Mortimer et al. 1999). This suggests they may play an important role in remobilisation of the nutrients bound to the terrestrial sediments and thus the recovery of the deposits in the longer term.

While the results of our previous experiments suggested that macrofaunal recovery would not occur within this short (4.5 mo) experimental period (Norkko et al. 2002, Hewitt et al. in press, Thrush et al. in press), we had expected to see more signs of change in the sediment characteristics. Most of the properties exhibited clear differences between the control plots and the terrestrial sediments. Terrestrial sediments had consistently lower porewater $\mathrm{NH}_{4}-\mathrm{N}$, coarse and medium sand, chl a and chl a: phaeophytin ratios, and higher levels of carbohydrate, protein, $\mathrm{N}, \mathrm{P}, \% \mathrm{C}$, organic content, fine sand, silt, clay and shear strength, relative to the control treatment sediments. Microbial biomass, phaeophytin and sediment penetrability were the only properties measured that did not show consistent differences between the control and terrestrial sediment treatments.

The controls in this experiment are essentially the natural sandflat, where the benthic community is already well established; thus we did not test for the effect of addition of marine sediment to the sandflat. However, we do not believe this would account for the significant differences in either the physical properties or the colonists present between the terrestrial sediment and control treatments. The reasons for this are 2-fold: (1) previous work has illustrated that escape of resident infauna smothered by 'like' sediment (i.e. similar to that they are currently living in) is much more likely than if they are smothered by 'exotic' sediment (i.e. sediment of different grain size), and it is has been 
well documented that mortality following deposition increases with sediment silt-clay content (e.g. Kranz 1974, Maurer et al. 1981a,b, Turk \& Risk 1981, Chandrasekara \& Frid 1998, authors' unpubl. data); and (2) our more recent experiments have demonstrated much higher recolonisation of defaunated marine sediment additions than of terrestrial sediment additions (R. Whitlatch \& V. Cummings unpubl. data).

There was no consistent distinction between the 3 terrestrial sediment treatments in terms of their macrofaunal communities or sediment properties (with the exception of protein) during the experiment. While the protein content of the S70 treatment was significantly higher than that of the S50 treatment on all sampling dates, this did not translate to differences in the type or number of macrofauna colonising the plots over the timescale of the experiment. These results indicate that the way terrestrial sediment enters the estuary does not affect the impact on the existing macrofaunal communities or their subsequent recovery. It also verifies and increases the generality of the results of our previous sedimentation experiments, in which only one method of terrestrial sediment preparation was used (Norkko et al. 2002, Hewitt et al. in press, Thrush et al. in press).

\section{Sediment characteristics correlated with macrofauna}

Levels of chl $a, \mathrm{P}$ and $\mathrm{N}$ were the sediment properties most important in structuring the control plot communities, and together they explained $76 \%$ of the variability in community composition over the experiment. Of these 3 properties, the amount of chl a present was the most important. Chl a was generally 2.5 to 6 times higher in the control plot sediments. The chl a:phaeophytin ratio was also higher in these plots, indicating they contained a much greater proportion of available food (i.e. 5 to 40 times more; Fig. 8F) than the terrestrial sediment deposits. Interestingly, the temporal change in the chl a:phaeophytin ratio in the control plots was very similar to that of the abundance and diversity of taxa (cf. Figs. 3A,B \& 8F), suggesting that small, relatively mobile macrofauna are able to select areas which are 'food-rich' as suitable habitats. Recent experiments have also documented the positive relationship between chl a as a food source and macrofaunal abundance. For example, Stocks \& Grassle (2001) found recolonisation by macrofauna was $62 \%$ lower in areas with reduced microalgal abundance. Similarly, laboratory experiments by Nilsson et al. (2000) showed that oligochaetes responded negatively to small patches of food-depleted sediments. The depleted levels of chl $a$ in our experiment may be partly due to the extreme cohesiveness and thickness of the terrestrial sediment layers preventing migration of the buried benthic diatoms back to the sediment surface. A study of the effect of thin silt deposits on microbenthos found that this active migration of diatoms was also a key mechanism for restoring oxygenation of the sediment surface (Wulff et al. 1997). The lack of oxygenation of the terrestrial sediments undoubtedly restricted the niches available to colonists in our study (e.g. see Fetzer et al. 2002).

Total sediment $\mathrm{P}$ was 3 to 7 times higher in the terrestrial sediments than in the control sediments throughout the experiment (Fig. 7). Due to the highly charged nature of both the $\mathrm{P}$ and clay particles, it is likely that the $\mathrm{P}$ associated with the terrestrial sediment treatments is very tightly bound and thus not 'available' to the microphytobenthos. Sediment $P$, along with \% coarse sand, total carbohydrate and penetrability, was also important in driving the distinction between the macrofaunal communities of the terrestrial sediment and control treatments. Together these 4 variables explained almost $30 \%$ of the variability in community composition over the experiment. While coarse sand was identified as important, there was never any in the terrestrial sediments, and it is likely to be a surrogate for some other limiting sediment characteristics (Gray 1974). The importance of penetrability is more likely to be a reflection of the 'fluidity' of the terrestrial sediments on the first few sampling occasions: as these plots dried out, their penetrability became similar to that of the control sediments (Fig. 7). Total carbohydrate content was considerably elevated in the terrestrial sediment treatments. However, a drop in total carbohydrate content associated with an increase in microbial biomass was noted on Day 93 in all terrestrial sediment treatments (Fig. 8), perhaps suggesting a slight recovery.

There was a much higher amount of organic matter associated with the terrestrial sediments, yet the lack of colonisation in these plots indicates it was obviously not available to the macrofauna. Stable isotope analysis was conducted on sediment samples collected from each replicate experimental plot on Day 23 only (using methods described in Gibbs et al. 2001). This revealed $\delta^{13} \mathrm{C}$ values for the terrestrial sediment plots of less than $-25.9 \%$ for all but 2 replicates $(-21.6$ and $-22.4 \%)$ compared with values of -13.6 to $-14.1 \%$ for the control plot sediments. These values indicate that the control plot sediments are more enriched with 'biologically available' material than the terrestrial sediments. Our study provides further evidence to show that, while terrestrially derived organic material commonly enters estuaries in relatively large amounts when associated with sedimentation events, it does not necessarily represent a nutritionally important or utilisable food source (e.g. Sobczak et al. 2002). 


\section{Burrowing crabs}

The importance of bioturbating fauna in increasing sediment resuspension, erodability and nutrient exchange is well known (e.g. Pelegri \& Blackburn 1994, Hansen \& Kristensen 1997, Mortimer et al. 1999). A large influx of juvenile crabs was indicated by an abundance of small burrow holes in the terrestrial sediment deposits early on in our experiment, and there was clear evidence of persistence and growth of the crabs (increase in burrow size) on subsequent sampling occasions. However, our core sampling did not detect large numbers of burrowing crabs in the plots, probably due to the small size of the corer used. Crab burrows were not found at all in the control plot sediments. A study examining the trophic relationships between macrofauna and terrestrial sediment deposits found strong evidence that crabs which quickly colonise terrestrial sediment deposits are not in fact feeding on the terrestrial material (Gibbs et al. 2001). Thus, the rapid colonisation of the deposits by crabs in our experiment (as also noted by Norkko et al. 2002, Hewitt et al. in press, Thrush et al. in press), is simply a response to finding a substrate that is more suitable for building and maintaining burrows in rather than the surrounding sandier sediments, and also rather than exploiting a new food source. In the longer term, the burrowing activities of these crabs will be important in the remobilisation of the experimental plot sediments, and the recovery of the macrofauna (Norkko et al. 2002, Hewitt et al. in press, Thrush et al. in press).

\section{Settlement cues}

Waterborne, organism- and process-specific (sensu Woodin et al. 1995) chemical cues have been shown to induce settlement and metamorphosis in larvae of many marine invertebrates (e.g. Scheltema 1974, Pearce \& Scheibling 1990, O'Connor \& Judge 1997, Woodin et al. 1997). Larvae and juveniles of some species can differentiate between disturbed and undisturbed surface (top few $\mathrm{mm}$ ) sediments (Woodin et al. 1995), in response to short-term (h) changes in gradients of solutes, such as oxygen (Marinelli \& Woodin 2002) and ammonium (Woodin et al. 1998). In the latter case, arenicolid polychaete recruits rejected sediments where ammonium levels were high and similar to those found in disturbed sediments. However, in our long-term study, porewater $\mathrm{NH}_{4}-\mathrm{N}$ does not appear to be an important cue for colonising macrofauna given that concentrations were considerably lower in the terrestrial sediment deposits than in the control sediments throughout the experiment. Measurements of other pore-water associated substances may be useful in future studies of recolonisation of terrestrial sediment deposits. Mixing of porewater solutes with the overlying water when the sandflat is immersed by the tide may provide an important cue for juveniles of some soft-sediment macrofaunal species that drift over the site in the water column. These juveniles may be able to detect process-specific solute gradients close to the sediment-water interface, thereby assessing the biogeochemical properties of the surficial sediments (and thus habitat suitability) without having to physically contact the sediment surface. For example, Krug \& Zimmer (2000) showed that complex carbohydrates contained in the porewater of algal patches that were released into the overlying water initiated a behavioural response in opistobranch larvae. Furthermore, they showed that the amount released was greatest early in the flood tide, suggesting that larvae carried into the algal patches during the first few minutes of a high tide should have a greater chance of settling in response to this cue than larvae transported later in the high tide. This has wider implications for the observed differences in the water-column associated dispersal of post-settlement stages of soft-sediment macrofauna dependent on the stage of the tidal cycle (e.g. Commito et al. 1995, Cummings et al. 1995, Whitlatch \& Osman 1998), and suggests that perhaps these fauna are adapted to optimum cue-detection times. Investigations into these hypotheses are currently in progress.

\section{CONCLUSIONS}

This study has provided further evidence of the persistence of terrestrial sediment deposits on an intertidal sandflat. A large number of sediment properties, which are potentially important as cues for habitat suitability to colonising macrofauna, are remarkably different to those of the surrounding sandflat, and showed little signs of change in the several months following deposition. Despite this, we were able to identify that macrofaunal community composition is strongly correlated with the amounts of chl $a_{1}$ carbohydrate, $\mathrm{P}, \mathrm{N}$ and coarse sand in the sediments, levels of which were considerably depleted (in the case of chl $a$ and coarse sand) or elevated ( $\mathrm{P}, \mathrm{N}$ and carbohydrate) in the terrestrial sediments. We recommend that future studies of macrofaunal recolonisation following deposition of terrestrial sediment include measurement of these sediment properties. In addition, analyses which isolate the biologically available portions of the carbohydrate, $\mathrm{P}$ and $\mathrm{N}$ may provide even more insight as to the importance of these properties as settlement cues and indicators of recovery. Finally, the way terrestrial sediment enters the estuary does not appear to effect either its impact on the existing macrofaunal communities or their subsequent recovery. 
Elevated rates of sedimentation in marine environments as a result of human activities is a recognised problem. With predictions of higher rainfall associated with global warming, there is a risk that sedimentation will increase in the future. Thus, it is important to develop a mechanistic understanding of the impact and subsequent recovery of sediment deposits in the marine environment, to enable us to predict the magnitude, extent and persistence of such events on marine habitats and, hopefully, to enable us to mitigate any detrimental effects.

Acknowledgements. Thanks to Greig Funnell, Joanne Ellis, Diane Schultz, Rick Liefting, Terry Hume and Iain MacDonald for their invaluable help in setting up and sampling this experiment (and especially for standing up to the armpits in water for hours waiting for the tide to go out!). Max Gibbs made valuable comments on a draft manuscript. Environment Waikato kindly gave their permission to conduct the experiment in the Whangapoua Estuary. This work was funded by NIWA-NSOF (NRK022) and the New Zealand Foundation for Research Science and Technology (FRST-CO1X0024).

Appendix 1. Results of generalised linear modelling for treatment effects on macrofaunal and colonising macrofaunal core data. Where a significant Time $\times$ Treatment interaction $(\mathrm{T} \times$ Tr) occurred, the treatment $\mathrm{p}$-value for each day is also given. For the number of individuals and number of taxa for both the macrofauna and colonising macrofauna core data, a Poisson distribution was used. When a quasi-likelihood function was used in the model, no p-value is given. Although block was included in the model, the results are not given here for reasons of brevity

\begin{tabular}{|llrrr|}
\hline Variable & Factor & p-value & $\begin{array}{c}\text { Time } \\
\text { (Day) }\end{array}$ & p-value \\
& & & & \\
Macrofauna & & & & \\
No. of ind. & Time & 0.0003 & 127 & $<0.0001$ \\
& Treatment & $<0.0001$ & 6 & $<0.0001$ \\
& T $\times$ Tr & $<0.0001$ & & \\
No. of taxa & Time & 0.0718 & 127 & 0.0013 \\
& Treatment & $<0.0001$ & 6 & 0.0004 \\
& T $\times$ Tr & 0.0651 & & \\
Colonising macrofauna & & & \\
No. of ind. & Time & 0.0022 & & \\
& Treatment & $<0.0001$ & & \\
No. of taxa & T $\times$ Tr & 0.4151 & & \\
& Time & 0.1107 & & \\
& Treatment & $<0.0001$ & & \\
Aquilaspio & T $\times$ Tr & 0.9829 & & \\
aucklandica & Time & 0.5095 & & \\
& Treatment & $<0.0001$ & & \\
Nereids & $\mathrm{T} \times \operatorname{Tr}$ & 0.3062 & & \\
& Time & 0.0471 & & \\
& Treatment & $<0.0001$ & & \\
& $\mathrm{~T} \times \operatorname{Tr}$ & 0.8243 & & \\
& & & & \\
& & &
\end{tabular}

Appendix 2. Results of generalised linear modelling for treatment effects on sediment properties. Where a significant Time $\times$ Treatment $(\mathrm{T} \times \mathrm{Tr})$ interaction occurred, the treatment $\mathrm{p}$ value for each day is also given. Although block was included in the model, the results are not given here for reasons of brevity. LOI: loss on ignition

\begin{tabular}{|c|c|c|c|c|}
\hline Variable & Factor & p-value & $\begin{array}{l}\text { Time } \\
\text { (Day) }\end{array}$ & p-value \\
\hline $\begin{array}{l}\% \text { Coarse } \\
\text { sand }\end{array}$ & $\begin{array}{l}\text { Time } \\
\text { Treatment } \\
\mathrm{T} \times \operatorname{Tr}\end{array}$ & $\begin{array}{r}0.2612 \\
<0.0001 \\
0.1296\end{array}$ & & \\
\hline $\begin{array}{l}\% \text { Medium } \\
\text { sand }\end{array}$ & $\begin{array}{l}\text { Time } \\
\text { Treatment } \\
\mathrm{T} \times \operatorname{Tr}\end{array}$ & $\begin{array}{r}0.0043 \\
<0.0001 \\
0.0010\end{array}$ & $\begin{array}{r}36 \\
50 \\
93 \\
127\end{array}$ & $\begin{array}{r}<0.0001 \\
0.3319 \\
0.0001 \\
0.0241\end{array}$ \\
\hline $\begin{array}{l}\% \text { Fine } \\
\text { sand }\end{array}$ & $\begin{array}{l}\text { Time } \\
\text { Treatment } \\
\mathrm{T} \times \operatorname{Tr}\end{array}$ & $\begin{array}{r}<0.0001 \\
<0.0001 \\
0.8251\end{array}$ & & \\
\hline$\%$ Silt & $\begin{array}{l}\text { Time } \\
\text { Treatment } \\
\mathrm{T} \times \operatorname{Tr}\end{array}$ & $\begin{array}{r}<0.0001 \\
<0.0001 \\
0.0718\end{array}$ & $\begin{array}{r}36 \\
50 \\
93 \\
127\end{array}$ & $\begin{array}{l}0.0206 \\
0.1728 \\
0.0250 \\
0.0050\end{array}$ \\
\hline \% Clay & $\begin{array}{l}\text { Time } \\
\text { Treatment } \\
\mathrm{T} \times \operatorname{Tr}\end{array}$ & $\begin{array}{r}<0.0001 \\
<0.0001 \\
0.0072\end{array}$ & $\begin{array}{r}36 \\
50 \\
93 \\
127\end{array}$ & $\begin{array}{l}0.0170 \\
0.1831 \\
0.0170 \\
0.0105\end{array}$ \\
\hline $\begin{array}{l}\text { Penetra- } \\
\text { bility }\end{array}$ & $\begin{array}{l}\text { Time } \\
\text { Treatment } \\
\mathrm{T} \times \operatorname{Tr}\end{array}$ & $\begin{array}{r}<0.0001 \\
<0.0001 \\
0.2130\end{array}$ & & \\
\hline $\begin{array}{l}\text { Shear } \\
\text { strength }\end{array}$ & $\begin{array}{l}\text { Time } \\
\text { Treatment } \\
\mathrm{T} \times \operatorname{Tr}\end{array}$ & $\begin{array}{l}<0.0001 \\
<0.0001 \\
<0.0001\end{array}$ & $\begin{array}{r}36 \\
50 \\
93 \\
127\end{array}$ & $\begin{array}{l}0.0659 \\
0.0029 \\
0.0195 \\
0.0047\end{array}$ \\
\hline $\begin{array}{l}\text { Carbo- } \\
\text { hydrate }\end{array}$ & $\begin{array}{l}\text { Time } \\
\text { Treatment } \\
\mathrm{T} \times \operatorname{Tr}\end{array}$ & $\begin{array}{r}<0.0001 \\
<0.0001 \\
0.0017\end{array}$ & $\begin{array}{r}36 \\
50 \\
93 \\
127\end{array}$ & $\begin{array}{r}<0.0001 \\
0.0050 \\
0.0005 \\
0.0036\end{array}$ \\
\hline Protein & $\begin{array}{l}\text { Time } \\
\text { Treatment } \\
\mathrm{T} \times \operatorname{Tr}\end{array}$ & $\begin{array}{r}<0.0001 \\
<0.0001 \\
0.2232\end{array}$ & & \\
\hline $\begin{array}{l}\text { Microbial } \\
\text { biomass }\end{array}$ & $\begin{array}{l}\text { Time } \\
\text { Treatment } \\
\mathrm{T} \times \operatorname{Tr}\end{array}$ & $\begin{array}{r}<0.0001 \\
0.8044 \\
0.5672\end{array}$ & & \\
\hline Chl a & $\begin{array}{l}\text { Time } \\
\text { Treatment } \\
\mathrm{T} \times \operatorname{Tr}\end{array}$ & $\begin{array}{r}<0.0001 \\
<0.0001 \\
0.9972\end{array}$ & & \\
\hline $\begin{array}{l}\text { Phaeo- } \\
\text { phytin }\end{array}$ & $\begin{array}{l}\text { Time } \\
\text { Treatment } \\
\mathrm{T} \times \operatorname{Tr}\end{array}$ & $\begin{array}{l}0.0004 \\
0.2992 \\
0.0011\end{array}$ & $\begin{array}{r}36 \\
50 \\
93 \\
127\end{array}$ & $\begin{array}{l}0.0988 \\
0.1041 \\
0.0643 \\
0.1352\end{array}$ \\
\hline Chla:Phaeo & $\begin{array}{l}\text { Time } \\
\text { Treatment } \\
\mathrm{T} \times \operatorname{Tr}\end{array}$ & $\begin{array}{r}0.2581 \\
<0.0001 \\
0.3022\end{array}$ & & \\
\hline $\begin{array}{l}\text { Porewater } \\
\mathrm{NH}_{4}-\mathrm{N}\end{array}$ & $\begin{array}{l}\text { Time } \\
\text { Treatment } \\
\mathrm{T} \times \operatorname{Tr}\end{array}$ & $\begin{array}{l}<0.0001 \\
<0.0001 \\
<0.0001\end{array}$ & $\begin{array}{r}36 \\
50 \\
93 \\
127\end{array}$ & $\begin{array}{l}0.0147 \\
0.5118 \\
0.3882 \\
0.0039\end{array}$ \\
\hline $\mathrm{P}$ & $\begin{array}{l}\text { Time } \\
\text { Treatment } \\
\mathrm{T} \times \operatorname{Tr}\end{array}$ & $\begin{array}{r}<0.0001 \\
<0.0001 \\
0.0001\end{array}$ & $\begin{array}{r}36 \\
50 \\
93 \\
127\end{array}$ & $\begin{array}{r}<0.0001 \\
0.0125 \\
<0.0001 \\
0.0027\end{array}$ \\
\hline $\mathrm{N}$ & $\begin{array}{l}\text { Time } \\
\text { Treatment } \\
\mathrm{T} \times \operatorname{Tr}\end{array}$ & $\begin{array}{c}<0.0001 \\
<0.0001 \\
0.0003\end{array}$ & $\begin{array}{r}36 \\
50 \\
93 \\
127\end{array}$ & $\begin{array}{c}<0.0001 \\
0.0067 \\
<0.0001 \\
0.0141\end{array}$ \\
\hline$\% \mathrm{C}$ & $\begin{array}{l}\text { Time } \\
\text { Treatment } \\
\mathrm{T} \times \operatorname{Tr}\end{array}$ & $\begin{array}{c}0.0050 \\
<0.0001 \\
0.8005\end{array}$ & & \\
\hline $\begin{array}{l}\% \text { Organic } \\
\text { content } \\
\text { (LOI) }\end{array}$ & $\begin{array}{l}\text { Time } \\
\text { Treatment } \\
\mathrm{T} \times \operatorname{Tr}\end{array}$ & $\begin{array}{l}<0.0001 \\
<0.0001 \\
<0.0001\end{array}$ & $\begin{array}{r}36 \\
50 \\
93 \\
127\end{array}$ & $\begin{array}{r}0.0009 \\
<0.0001 \\
0.0014 \\
0.0398\end{array}$ \\
\hline
\end{tabular}




\section{LITERATURE CITED}

APHA (American Public Health Association) (1998) Standard methods for the examination of water and wastewater, 20th edn. American Public Health Association, Washington, DC

Burd B, Macdonald R, Boyd B (2000) Punctuated recovery of sediments and benthic infauna; a 19-year study of tailings deposition in a British Columbia fjord. Mar Environ Res 49:145-175

Chandrasekara WU, Frid CLJ (1998) A laboratory assessment of the survival and vertical movement of 2 epibenthic gastropod species, Hydrobia ulvae (Pennant) and Littorina littorea (Linnaeus), after burial in sediment. J Exp Mar Biol Ecol 221:191-207

Commito JA, Thrush SF, Pridmore RD, Hewitt JE, Cummings VJ (1995) Dispersal dynamics in a wind-driven benthic system. Limnol Oceanogr 40:1513-1518

Cummings VJ, Pridmore RD, Thrush SF, Hewitt JE (1995) Post-settlement movement by intertidal benthic macrofauna: do common New Zealand species drift in the water column? NZ J Mar Freshw Res 29:59-67

Cundy AB, Collins PEF, Turner SD, Croudace IW, Horne D (1998) 100 years of environmental change in a coastal wetland, Augusta Bay, southeast Sicily: evidence from geochemical and paleoecological studies. In: Black KS, Paterson DM, Cramp A (eds) Sedimentary processes in the intertidal zone, Vol 139. Geological Society Special Publications, London, p 243-254

Davies PE, Nelson M (1993) The effect of steep slope logging on fine sediment infiltration into the beds of ephemeral and perennial streams of the Dazzler Range, Tasmania, Australia. J Hydrol 150:481-504

Doeg TJ, Koehn JD (1990) A review of Australian studies on the effects of forestry practices on aquatic values. Silvicultural Systems Project Technical Report No. 5. Department of Conservation and Environment, Melbourne, p 81

Ellis JI, Thrush SF, Norkko A (2000) Broad-scale disturbance of intertidal and shallow sublittoral soft-sediment habitats: effects on the benthic macrofauna. J Aquat Ecosyst Stress Recovery 7:57-74

Fahey BD, Coker RJ (1992) Sediment production from forest roads in Queen Charlotte Forest and potential impact on marine water quality, Marlborough Sounds, New Zealand. NZ J Mar Freshw Res 26:187-195

Fetzer I, Lonne OJ, Pearson T (2002) The distribution of juvenile benthic invertebrates in an arctic glacial fjord. Polar Biol 25:303-315

Findlay RH, King GM, Watling L (1989) Efficacy of phospholipid analysis in determining microbial biomass in sediments. Appl Environ Microbiol 55(11):2888-2893

Flemming BW, Delafontaine MT (2000) Mass physical properties of muddy intertidal sediments: some applications, misapplications and non-applications. Cont Shelf Res 20: 1179-1197

Foster G, Carter L (1997) Mud sedimentation on the continental shelf at an accretionary margin-Poverty Bay, New Zealand. NZ J Geol Geophys 40:157-173

GESAMP (Group of Experts on the Scientific Aspects of Marine environmental Protection) (1994) Anthropogenic influences on sediment discharge to the coastal zone and environmental consequences. UNESCO-TOC, Paris

Gibbs M, Thrush S, Ellis J (2001) Terrigenous clay deposition on estuarine sandflats: using stable isotopes to determine the role of the mud crab, Helice crassa Dana, in the recovery process. Isotopes Environmental Health Studies 37: $113-131$
Gray JS (1974) Animal-sediment relationships. Oceanogr Mar Biol Annu Rev 12:223-261

Gray JS (1997) Marine biodiversity: patterns, threats and conservation needs. Biodivers Conserv 6:153-175

Grayson RB, Haydon SR, Jayasuriya MDA, Finlayson BL (1993) Water quality in mountain ash forests - separating the impacts of roads from those of logging operations. J Hydrol 150:459-480

Hansen K, Kristensen E (1997) Impact of macrofaunal recolonization on benthic metabolism and nutrient fluxes in a shallow marine sediment previously overgrown with macroalgal mats. Estuar Coast Shelf Sci 45:613-628

Hartree EF (1972) Determination of protein. Anal Biochem 48: 422-427

Hewitt JE, Cummings VJ, Ellis JI, Funnell G, Norkko A, Talley TS, Thrush SF (in press) The role of waves in the colonisation of terrestrial sediments deposited in the marine environment. J Exp Mar Biol Ecol

Johnston A, Mace J, Laffan M (1981) The saw, the soil and the Sounds. Soil Water 17:4-6

Kranz PM (1974) The anastrophic burial of bivalves and its paleoecological significance. J Geol 82:237-265

Krug PJ, Zimmer RK (2000) Larval settlement: chemical markers for tracing production, transport, and distribution of a waterborne cue. Mar Ecol Prog Ser 207:283-296

Legendre P, Gallagher ED (2001) Ecologically meaningful transformations for ordination of species data. Oecologia 129:271-280

Liu D, Wong PTS, Dutka BJ (1973) Determination of carbohydrate in lake sediment by a modified phenol-sulfuric acid method. Water Res 7:741-746

Lundin CG, Linden O (1993) Coastal ecosystems: attempts to manage a threatened resource. Ambio 22:468-473

Marinelli RL, Woodin SA (2002) Experimental evidence for linkages between infaunal recruitment, disturbance, and sediment surface chemistry. Limnol Oceanogr 47: 221-229

Maurer D, Keck RT, Tinsman JC, Leathem WA (1981a) Vertical migration and mortality of benthos in dredged material. Part I. Mollusca. Mar Environ Res 4:299-319

Maurer D, Keck RT, Tinsman JC, Leathem WA (1981b) Vertical migration and mortality of benthos in dredged material. Part II. Crustacea. Mar Environ Res 5:301-317

Mayer LM, Schick LL, Setchell F (1986) Measurement of protein in nearshore marine sediments. Mar Ecol Prog Ser 30:159-165

Mayer LM, Schick LL, Sawyer T, Plante C, Jumars PA, Self RL (1995) Bioavailable amino acids in sediments: a biomimetic, kinetics-based approach. Limnol Oceanogr 40: $511-520$

McKnight DG (1969) A recent, possibly catastrophic burial in a marine molluscan community. NZ J Mar Freshw Res 3: $177-179$

Meade RH (1969) Errors in using modern stream-load data to estimate natural rates of denudation. Geol Soc Am Bull 80:1265-1274

Megahan WF, Kidd WJ (1972) Effects of logging and logging roads on erosion and sediment deposition from steep terrain. J For 70:135-141

Milliman JD, Meade RH (1983) World-wide delivery of river sediment to the oceans. J Geol 91:1-21

Mortimer RJG, Davey JT, Krom MD, Watson PG, Frickers PE, Clifton RJ (1999) The effect of macrofauna on porewater profiles and nutrient fluxes in the intertidal zone of the Humber Estuary. Estuar Coast Shelf Sci 48:683-699

Nichols MM (1977) Response and recovery of an estuary following a river flood. J Sediment Petrol 47:1171-1186 
Nilsson PG, Levinton JS, Kurdziel JP (2000) Migration of a marine oligochaete: induction of dispersal and microhabitat choice. Mar Ecol Prog Ser 207:89-96

Norkko A (1998) The impact of loose-lying algal mats and predation by the brown shrimp Crangon crangon (L.) on infaunal prey dispersal and survival. J Exp Mar Biol Ecol 221:99-116

Norkko A, Thrush SF, Hewitt JE, Cummings VJ and 5 others (2002) Smothering of estuarine sandflats by terrigenous clay: the role of wind-wave disturbance and bioturbation in site-dependent macrofaunal recovery. Mar Ecol Prog Ser 234:23-41

O'Connor N, Judge M (1997) Flexibility in timing of moulting of fiddler crab megalopae: evidence from in situ manipulation of cues. Mar Ecol Prog Ser 1997:55-60

Orbell GE (1973) Soils. In: Town and country planning division, Ministry of Works. National resources survey. Part VIII. Waikato Coromandel King Country Region. AR Shearer, Government Printer, Wellington, p 73-88

Pearce CM, Scheibling RE (1990) Induction of settlement and metamorphosis in the sand dollar Echinarachnius parma: evidence for and adult-associated factor. Mar Biol 107: 363-369

Pelegri S, Blackburn T (1994) Bioturbation effects of the amphipod Corophium volutator on microbial nitrogen transformations in marine sediments. Mar Biol 121:253-258

Peterson CH (1985) Patterns of lagoonal bivalve mortality after heavy sedimentation and their paleoecological significance. Paleobiology 11:139-153

Sartory DP (1982) Spectrophotometric analysis of chlorophyll a in freshwater phytoplankton. Report no. TR 115. Hydrological Research Institute, Department of Environment Affairs, Pretoria

Scheltema RS (1974) Biological interactions determining larval settlement of marine invertebrates. Thalassia Jugosl 10:263-296

Shaffer JA, Parks DS (1994) Seasonal variations in and observations of landslide impacts on the algal composition of a Puget Sound nearshore kelp forest. Bot Mar 37:315-323

Sobczak WV, Cloern JE, Jassby AD, Muller-Solger AB (2002) Bioavailability of organic matter in a highly disturbed estuary: the role of detrital and algal resources. PNAS 99: 8101-8105

Editorial responsibility: John Gray (Contributing Editor), Oslo, Norway
Stocks KI, Grassle JF (2001) Effects of microalgae and food limitation on the recolonization of benthic macrofauna into in situ saltmarsh-pond mesocosms. Mar Ecol Prog Ser 221: 93-104

Sutherland TF, Amos CL, Grant J (1998) The effect of buoyant biofilms on the erodability of sublittoral sediments of a temperate microtidal estuary. Limnol Oceanogr 43:225-235

Tallqvist M (2001) Burrowing behaviour of the Baltic clam Macoma balthica: effects of sediment type, hypoxia and predator presence. Mar Ecol Prog Ser 212:183-191

ter Braak CJF (1986) Canonical correspondence analysis: a new eigenvector technique for multivariate direct gradient analysis. Ecology 67:1167-1179

ter Braak CJF (1987) The analysis of vegetation-environment relationships by canonical correspondence analysis. Vegetatio 69:69-77

Thrush SF, Hewitt JE, Norkko A, Cummings VJ, Funnell GA (in press) Catastrophic sedimentation on estuarine sandflats: recovery of macrobenthic communities is influenced by a variety of environmental factors. Ecol Appl

Turk TR, Risk MJ (1981) Effect of sedimentation on infaunal invertebrate populations of Cobequid Bay, Bay of Fundy. Can J Fish Aquat Sci 38:642-648

Wheatcroft RA (2000) Oceanic flood sedimentation: a new perspective. Cont Shelf Res 20:2059-2066

Wheatcroft RA, Sommerfield CK, Drake DE, Borgeld JC, Nittrouer CA (1997) Rapid and widespread dispersal of flood sediment on the northern California margin. Geology 25: 163-166

Whitlatch R, Osman R (1998) A new device for studying benthic invertebrate recruitment. Limnol Oceanogr 43:516-523

Woodin SA, Lindsay SM, Wethey DS (1995) Process-specific recruitment cues in marine sedimentary systems. Biol Bull 189:49-58

Woodin SA, Lindsay SM, Lincoln DE (1997) Biogenic bromophenols as negative recruitment cues. Mar Ecol Prog Ser 157:303-306

Woodin SA, Marinelli RL, Lindsay SM (1998) Process-specific cues for recruitment in sedimentary environments: geochemical signals? J Mar Res 56:535-558

Wulff A, Sundback K, Nilsson C, Carlson L, Jonsson B (1997) Effect of sediment load on the microbenthic community of a shallow-water sandy sediment. Estuaries 20:547-558

Submitted: July 25, 2002; Accepted: January 23, 2003

Proofs received from author(s): April 29, 2003 